ORIGINAL ARTICLE / ARTIGO ORIGINAL

\title{
Epidemiology and burden of chronic respiratory diseases in Brazil from 1990 to 2017: analysis for the Global Burden of Disease 2017 Study
}

\author{
Epidemiologia e carga das doenças respiratórias crônicas no Brasil de 1990 \\ a 2017: análise do Estudo Global Burden of Disease 2017
}

\author{
Lisiane Freitas Leal'," (D), Ewerton Cousin' (D), Augusto Bacelo Bidinotto' (D), \\ Daniel Sganzerla' (D), Rogério Boff Borges' (D), Deborah Carvalho Malta"l' (D), \\ Kevin Ikutalv (D), Tatiane da Silva Dal Pizzol' (iD
}

\begin{abstract}
Introduction: In Brazil, little is known about the trends of chronic respiratory diseases, which was estimated as the third leading cause of deaths in 2017 worldwide. Methods: We analyzed Global Burden of Disease (GBD) 2017 estimates for prevalence, incidence, mortality, disability-adjusted life years (DALY), a summary measure of years of life lost (YLLs) and years lived with disability (YLDs), and risk factors attributable to chronic respiratory diseases in Brazil from 1990 to 2017. Results: The overall estimates have decreased for all ages and both sexes, and for age-standardized rates. For age-adjusted prevalence, there was a $21 \%$ reduction, and nearly $16 \%$ reduction for incidence. There was a $42 \%$ reduction in mortality for both sexes, though the rate of deaths for men was $30 \%$ greater than the rate in women. The increase in the number of DALY was essentially due to the population growth and population ageing. We observed a $34 \%$ increase in the absolute number of DALY in Brazil over the study period. The majority of the DALY rates were due to Chronic Obstructive Pulmonary Disease (COPD). For all ages and both sexes, smoking was the main attributable risk factor. Conclusion: In Brazil, although mortality, prevalence and incidence for chronic respiratory diseases have decreased over the years, attention should be taken to the DALYs increase. Smoking remained as the main risk factor, despite the significant decrease of tobacco use, reinforcing the need for maintenance of policies and programs directed at its cessation.
\end{abstract}

Keywords: Respiratory Tract Diseases; Noncommunicable Diseases; Pulmonary Disease, Chronic Obstructive; Global Burden of Disease; Disability-Adjusted Life Years; Brazil

Universidade Federal do Rio Grande do Sul, Programa de Pós-Graduação em Epidemiologia, Porto Alegre, Rio Grande do Sul, Brazil. "McGill University, Department of Epidemiology, Biostatistics and Occupational Health, Montreal, Quebec, Canada.

"'Universidade Federal de Minas Gerais, Escola de Enfermagem, Departamento de Enfermagem Materno-Infantil e Saúde Pública, Belo Horizonte, Minas Gerais, Brazil.

IV University of Washington, Division of Allergy and Incetious Diseases, Seattle, Washington, Unitated States of America. Corresponding author: Lisiane Freitas Leal. 3,755 Cote Ste- Catherine, suite H-455, Montreal, QC H3T 1E2, Canada. E-mail: lisianeleal@ gmail.com

Conflicts of interests: nothing to declare - Financial support: This study was financed in part by the Coordenação deAperfeiçoamento de Pessoal de Nível Superior - Brasil (CAPES) - Finance Code 001 (Lisiane F. L., Ewerton C. and Augusto B. B. received the doctoral scholarship grant). Conselho Nacional de Desenvolvimento Científico e Tecnológico (CNPq) - (Deborah C. M. received a scholarship of productivity), TED 125/2017 (FNS - Secretaria de Vigilância em Saúde). 
RESUMO: Introdução: No Brasil, pouco se sabe sobre as tendências das doenças respiratórias crônicas, que foram estimadas como a terceira principal causa de mortes em 2017 em todo o mundo. Métodos: Analisamos as estimativas do Global Burden of Disease (GBD) 2017 para prevalência, incidência, mortalidade, anos de vida ajustados por incapacidade (DALY), uma medida resumida de anos de vida perdidos (YLL) e anos vividos com deficiência (YLD), e fatores de risco atribuíveis a doenças respiratórias crônicas no Brasil, de 1990 a 2017. Resultados: As estimativas gerais diminuíram para todas as idades e ambos os sexos, assim como para as taxas padronizadas por idade. Para a prevalência ajustada pela idade, houve uma redução de $21 \%$ e, aproximadamente, $16 \%$ para a incidência. Houve uma redução de $42 \%$ na mortalidade para ambos os sexos, embora a taxa de mortes para homens tenha sido $30 \%$ maior do que a taxa para mulheres. O aumento no número de DALY deveu-se ao crescimento e envelhecimento da população. Observamos um aumento de $34 \%$ no número absoluto de DALYs no Brasil durante o período do estudo. A maioria das taxas de DALY foi devido a Doença Pulmonar Obstrutiva Crônica (DPOC). Para todas as idades e ambos os sexos, tabagismo foi o principal fator de risco atribuível. Conclusão: No Brasil, embora a mortalidade, a prevalência e a incidência de doenças respiratórias crônicas tenham diminuído ao longo dos anos, maior atenção deve ser dada ao aumento dos DALYs. O tabagismo permaneceu como principal fator de risco, apesar da redução significativa do seu uso, reforçando a necessidade de manutenção de políticas e programas direcionados à sua cessação.

Palavras-chave: Doenças Respiratórias; Doenças não Transmissíveis; Doença Pulmonar Obstrutiva Crônica; Carga Global da Doença; Anos de Vida Ajustados pela Incapacidade; Brasil

\section{INTRODUCTION}

Chronic respiratory diseases are defined as a group of diseases that affect the lung and its structures ${ }^{1}$. These conditions, mainly consisting of chronic obstructive pulmonary disease (COPD) and asthma, have different epidemiologic profiles and sequelae depending on the age and other characteristics of those affected ${ }^{1-4}$.

Previous epidemiological estimates for chronic respiratory diseases have considerable heterogeneity worldwide, in part due to differences in study design. As a result, the estimates are not comparable, especially considering inequalities between high- and low-income countries ${ }^{4,5}$. Recently, the methods to assess aggregate data have improved, and it is now possible to evaluate and compare estimates and correct for sources of measurement bias ${ }^{6}$. In fact, the Global Burden of Disease Study (GBD), first published over 10 years ago and with regular updates to its estimates, has brought transparency and improvement to global health estimates?

In Brazil, population-based studies have contributed to estimating the impact of chronic respiratory diseases. The Latin American Project for the Investigation of Obstructive Lung Disease (PLATINO) provided estimates for $\mathrm{COPD}^{8-11}$, while the National Health Survey (PNS) has estimated the prevalence of asthma and COPD, as well as the degree to which these conditions limit everyday activities ${ }^{12}$. Another important contribution to Brazilian estimates was provided by the Brazilian National Household Survey (PNAD) ${ }^{13}$. 
Beyond the population-based studies, data on health-care conditions other than prevalence are provided by the Ministry of Health in which the main population-based information systems (with respective acronyms in Portuguese) are Mortality Information System (SIM), Live-Birth Information System (SINASC), Primary Care Information System (SIAB); Hospital Information System (SIH); Ambulatory Care Information System (SIA); and National System of Notifiable Events (SINAN) ${ }^{14}$. Brazilian estimates for chronic respiratory diseases, although available from these different sources, have not been aggregated so far, hampering the assessment of the burden of these conditions.

Previous studies using GBD results have demonstrated health improvements in the Brazilian population, including reduction in mortality due to chronic respiratory disease ${ }^{15,16}$. Nevertheless, to our knowledge, publications showing the behavior of such conditions over the years are still missing. To address these data gaps, we evaluate the prevalence, incidence, mortality, and burden due to chronic respiratory diseases in Brazil, as well as the risk factors to which these conditions are attributable, based on GBD estimates from 1990 to 2017.

\section{METHODS}

This is a descriptive study analyzing the epidemiology profile of chronic respiratory diseases in Brazil from 1990 to 2017. The estimates were extracted from the Institute for Health Metrics and Evaluation's (IHME) data visualizations tools ${ }^{17}$, which show results from GBD. The GBD 2017 utilized a range of data resources and uses statistical methods to aggregate data, adjust bias, and create new covariates for each group of metrics. This section provides a brief overview of GBD methodology, which has been published elsewhere ${ }^{6,18-20}$.

The main source of data for causes of death in Brazil is the SIM ${ }^{21}$. For the GBD, known as garbage codes ${ }^{22}$, causes that cannot be considered underlying causes of death (or causes that are implausible for other reasons) are redistributed to other underlying causes of deaths using a variety of methods. Once the garbage coded deaths have been redistributed the causes of death database is used as an input for the Cause of Death Ensemble modelling (CODEm) tool to estimate the cause of deaths ${ }^{18}$.

For estimates of prevalence, incidence, and years lived with disability (YLDs) GBD uses the DisMod-MR 2.1 tool $^{23}$, which utilizes Bayesian meta-regression. In Brazil, the source data for nonfatal health outcomes and covariates used to compute these estimates are mainly from SIH, survey data and other epidemiologic studies, such as the PLATINO, PNS and Brazil Surveillance System of Risk Factors for Chronic Diseases by Telephone Interviews (Vigitel) ${ }^{8,24,25}$.

Another metric used by GBD is the disability-adjusted life year (DALY). The DALY measures premature mortality and incapacity due to disease simultaneously ${ }^{20,26}$, as the sum of years of life lost (YLLs) and years lived with disability (YLDs). YLLs are computed by multiplying the number of deaths from chronic respiratory diseases in each age group by the reference life expectancy at the average age of death for those who die in that age group ${ }^{19}$. YLDs are calculated by multiplying chronic respiratory diseases sequelae prevalence by their disability weights in age-, sex-, and year-specific strata, in the presence of more than 
one disability condition was used the comorbidity correction (COMO), to adjust the estimates $^{27}$. The disability estimates and weights presented by GBD were obtained from population-based surveys of countries around the world ${ }^{19}$.

The ICD-10 codes for causes of death due to chronic respiratory diseases used by GBD were:

- asthma: J45-J46.9;

- COPD: J41-J44.9;

- pneumoconiosis: J60-J63.8, J65-J65.0, J92.0;

- interstitial lung disease and pulmonary sarcoidosis: D86-D86.2, D86.9, J84-J84.9;

- other chronic respiratory diseases: G47.3, J30-J35.9, J37-J39.9, J66-J68.9, J70, J70.8-J70.9, J82, J91-J92, J92.9.

ICD-9 codes was also used but only for estimates up to $1995^{18,23}$.

All metrics are estimated using 95\% uncertainty intervals (95\% UI), in which every estimate is calculated 1,000 times, assuming the time sampling from distributions rather than point estimates for data inputs, data transformations and model choice. The 95 th uncertainty interval is determined by the 25 th and 975 th value of the 1,000 ordered values ${ }^{18}$.

To understand the factors associated with the change in DALYs between 1990 and 2017, we used decomposition according to the Das Gupta method ${ }^{28}$. This analysis uses the estimated percent changes due specifically to growth in total population, population ageing, and change in DALY rates ${ }^{29}$. We also assess the DALYs attributable to risk factors for chronic respiratory diseases according to GBD classification, which include air pollution, occupational risks, tobacco, and high body-mass index.

We conducted this study using exclusively public secondary data available from $\mathrm{GBD}^{17}$. All procedures described followed the ethical principles of Resolution no. 466/2012 of the National Council of Health.

\section{RESULTS}

There was a decrease in both prevalence and incidence rates of chronic respiratory diseases in Brazil over the last 27 years. Figure 1 depicts changes in patterns of prevalence (Panel A) and incidence (Panel B) from 1990 to 2017. The overall estimates have decreased for all ages and both sexes, and for age-standardized rates. A slight reduction in prevalence was observed for all ages, from 9,226.7 (95\% UI = 8,136.6 - 10,367.3) prevalent cases per 100,000 in 1990 to $8,025.3$ (95\% UI $=7,312.0-8,775.5)$ prevalent cases per 100,000 in 2017 , which represented a reduction of approximately $13 \%$. For incidence, the estimates have reduced gradually over the period, with a reduction of nearly $16 \%$ for age-standardized and both sexes. The differences between estimates for women and men are also demonstrated in Figure 1. Across all years the estimated incidence and prevalence are larger in women than men. While there has been a gradual decrease for both sexes in prevalence, the incidence has been steady for women since 2005 . 
The mortality estimates for all ages, as well as age-standardized rates by sex, are presented in Figure 2. An absolute increase of deaths due to chronic respiratory diseases was observed for both women and men, for all ages, between 1990 and 2017 . When adjusted by age, however, an absolute decrease of nearly $42 \%$ for both sexes were observed, even though the rate of deaths for men, 44.1 deaths per $100,000(95 \%$ UI $=42.9-45.3)$ was $30 \%$ greater than the mortality rate for women (26.6 deaths per 100,000; 95\% UI $=25.7-27.5)$ in 2017 .

Concerning DALYs, Table 1 shows the decomposition of the number of DALYs between 1990 and 2017. The population growth accounted for an increase of $42 \%$, ageing of the population for an increase of $64 \%$, and change in the underlying age- and sex-standardized rates of DALYs for a decrease of $71 \%$, representing an overall increase of $34 \%$ in DALY rate due to chronic respiratory diseases over the period.

Figure 3 graphically represents the DALYs rate increase according to age range. The DALY rates due to asthma were greater for those younger than 20 years old, peaked in those aged 5 to 9 years, and then decreased until 20 years old. From 30 years old, the rates for COPD gradually rise, with a slight increase of interstitial lung diseases and asthma observed for those aged more than 60 years.

Finally, the rates of risk-attributable DALYs due to chronic respiratory diseases are shown in Figure 4. For all ages, smoking was the main risk factor. For male population, the disability due to smoking markedly decreased between 1990 and 2017, from 462.2 (95\% UI $=423.4-$ 501.4) DALYs per 100,000 persons to 389.4 (95\% UI = 349.9 - 428.8) DALYs per 100,000 persons, the same not occurring for female population, which reduction was roughly $7 \%$ when compared with $19 \%$ for men. The male population also was more affected by occupational
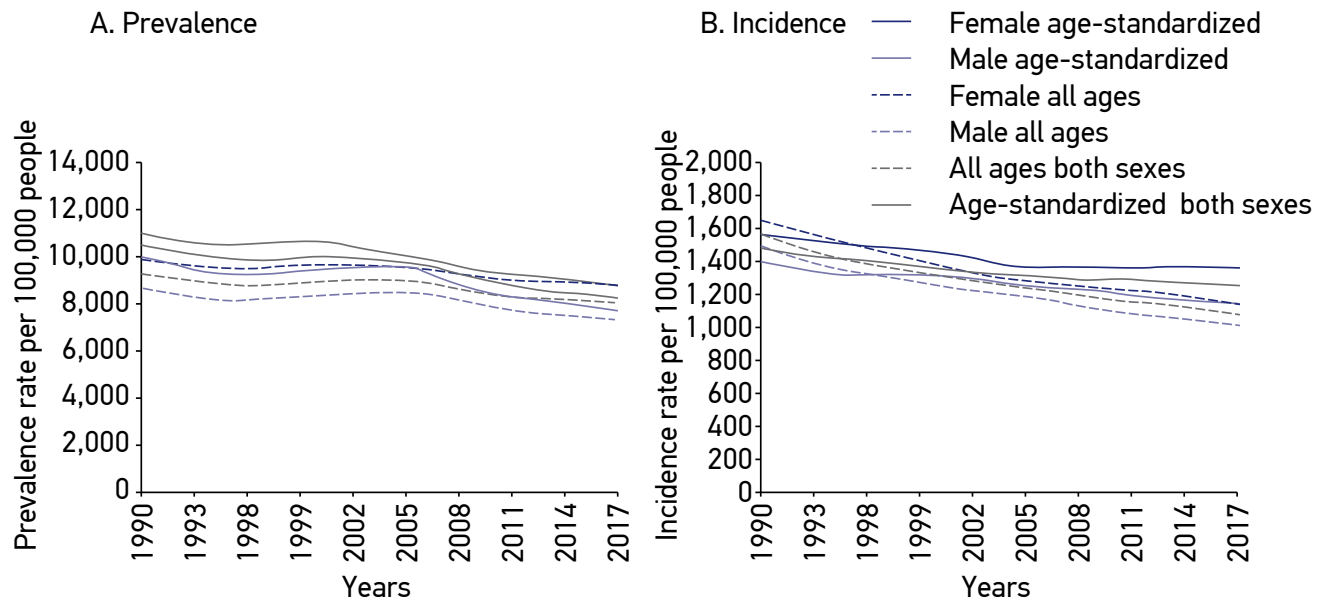

Figure 1. Epidemiology and burden of chronic respiratory diseases in Brazil from 1990 to 2017: analysis for the Global Burden of Diseases 2017: (A) prevalence rate of chronic respiratory diseases by sex age-standardized and for all ages between 1990 and 2017; (B) incidence rate of chronic respiratory diseases by sex age-standardized and for all ages between 1990 and 2017. 
particulate matter, without reduction occurring over the years, 140.4 (95\% UI $=115.3-$ 166.4 $)$ and $138.6(95 \% \mathrm{UI}=113.2-163.8)$ in 1990 and 2017, respectively. Household air pollution from solid fuels, which similarly affected men and women in 1990, 101.6 (95\% UI = 60.0 - 143.7) DALYs per 100,000 men and 103.8 (95\% UI $=65.0$ - 139.7) DALYs per 100,000 women, had its rates replaced by ambient particulate matter pollution for both sexes in 2017 .

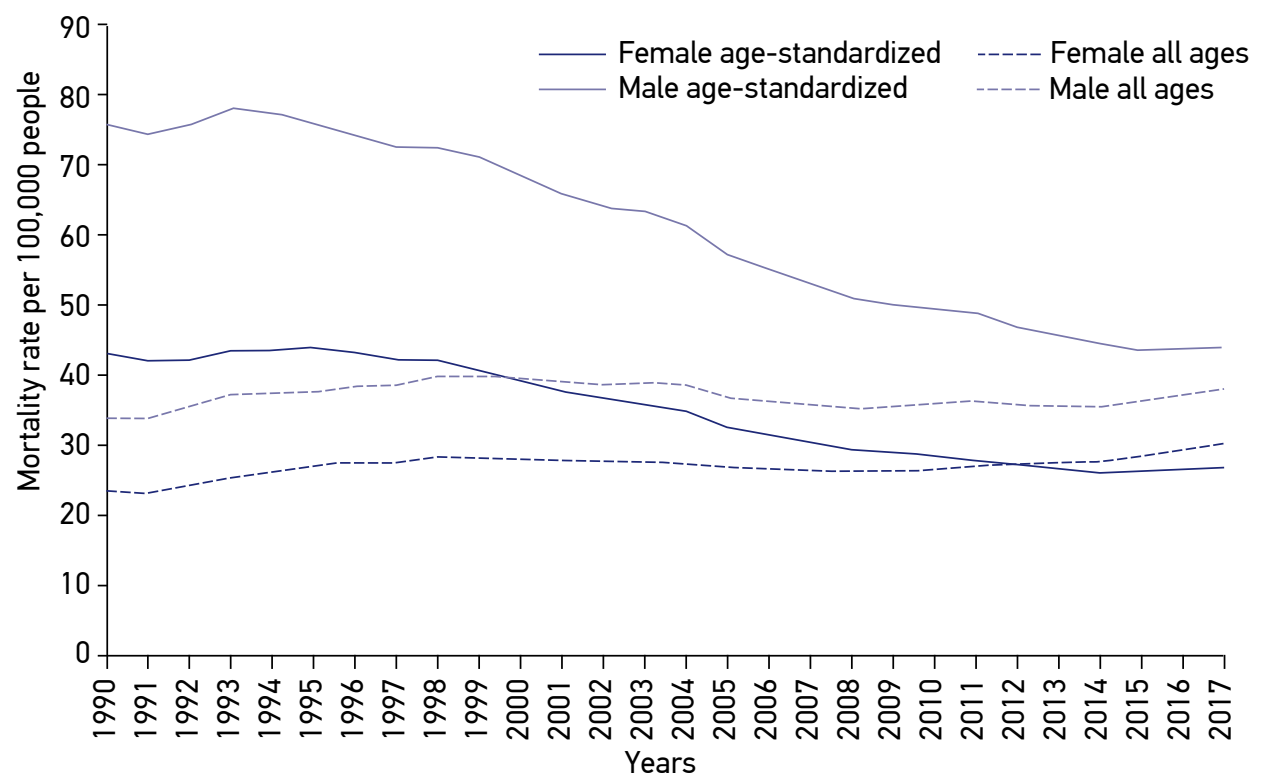

Figure 2. The mortality rate due to chronic respiratory diseases for all ages and age-standardized by sex, between 1990 and 2017.

Table 1. Decomposition analysis of the change in the number of disability-adjusted life years (DALY) (thousands) due to chronic respiratory diseases from 1990 to 2017 as being due to total population growth, population ageing, and changes in age-, sex-specific DALY rates.

\begin{tabular}{l|c}
\hline & Values \\
\hline 1990 DALYs & $1,601,765.14$ \\
\hline DALYs expected with 2017 population, 1990 population age structure, 1990 DALY rates & $2,270,590.00$ \\
\hline DALYs expected with 2017 population, 2017 population age structure, 1990 DALY rates & $3,288,766.00$ \\
\hline 2017 DALYs & $2,146,048.00$ \\
\hline Median percent change from 1990 due to population growth & $42 \%$ \\
\hline Median percent change from 1990 due to population ageing & $64 \%$ \\
\hline Median percent change from 1990 due to change in DALY rates & $-71 \%$ \\
\hline Median percent change from 1990 to 2017 (Total) & $34 \%$
\end{tabular}




\section{DISCUSSION}

Prevalence, incidence and mortality rates of chronic respiratory diseases have been decreasing in Brazil. Despite these improvements, the burden, shown by the DALY rates decomposition, has still risen mainly due to population growth and ageing, possibly associated with the epidemiological transition towards non-communicable diseases (NCD) and the ageing process in Brazil, accelerated after $2000^{16}$. Herein, COPD appeared as the chronic respiratory disease responsible for the growth of DALY with increasing age, a trend that was expected considering the profile of such diseases. Smoking is the main risk factor associated with DALY. The difference observed between sexes is notable and deserves attention.

The profile of respiratory conditions is in line with Brazilian estimates ${ }^{8,12,24}$, in which asthma and COPD have higher prevalence than other chronic respiratory conditions, similar to other countries ${ }^{2,30,31}$. Prevalence and incidence decreased for all-ages and age-standardized and, though decreasing for both sexes, estimates were higher for females. In general, the disease's occurrence is more frequent in women than in men, likely explained by the greater opportunity of women to receive a diagnosis when compared to men $^{32-34}$, whose preventive search for medical care is historically lower. Consequently, men have lower prevalence of diseases, not because of their better health condition, but mostly because they do not access the health care system. In this regard, policies to improve healthcare engagement for men have been created in Brazil ${ }^{35}$. Additionally, we highlight the high percentage of the population with COPD and other chronic respiratory conditions without proper diagnosis ${ }^{11}$, which means we are probably underestimating such diseases.

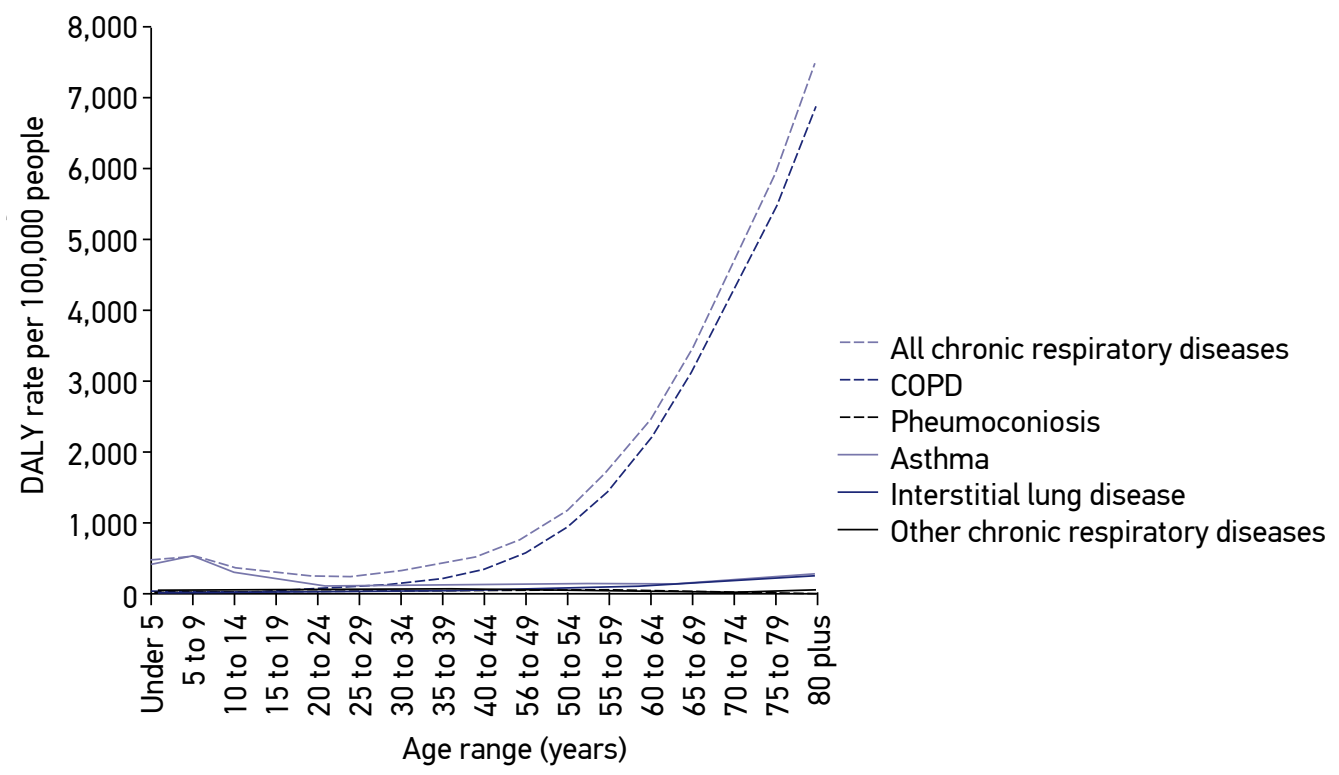

Figure 3. Disability-adjusted life-years (DALY) rates due to chronic respiratory diseases by condition and age range, both sexes, Brazil, 2017. 

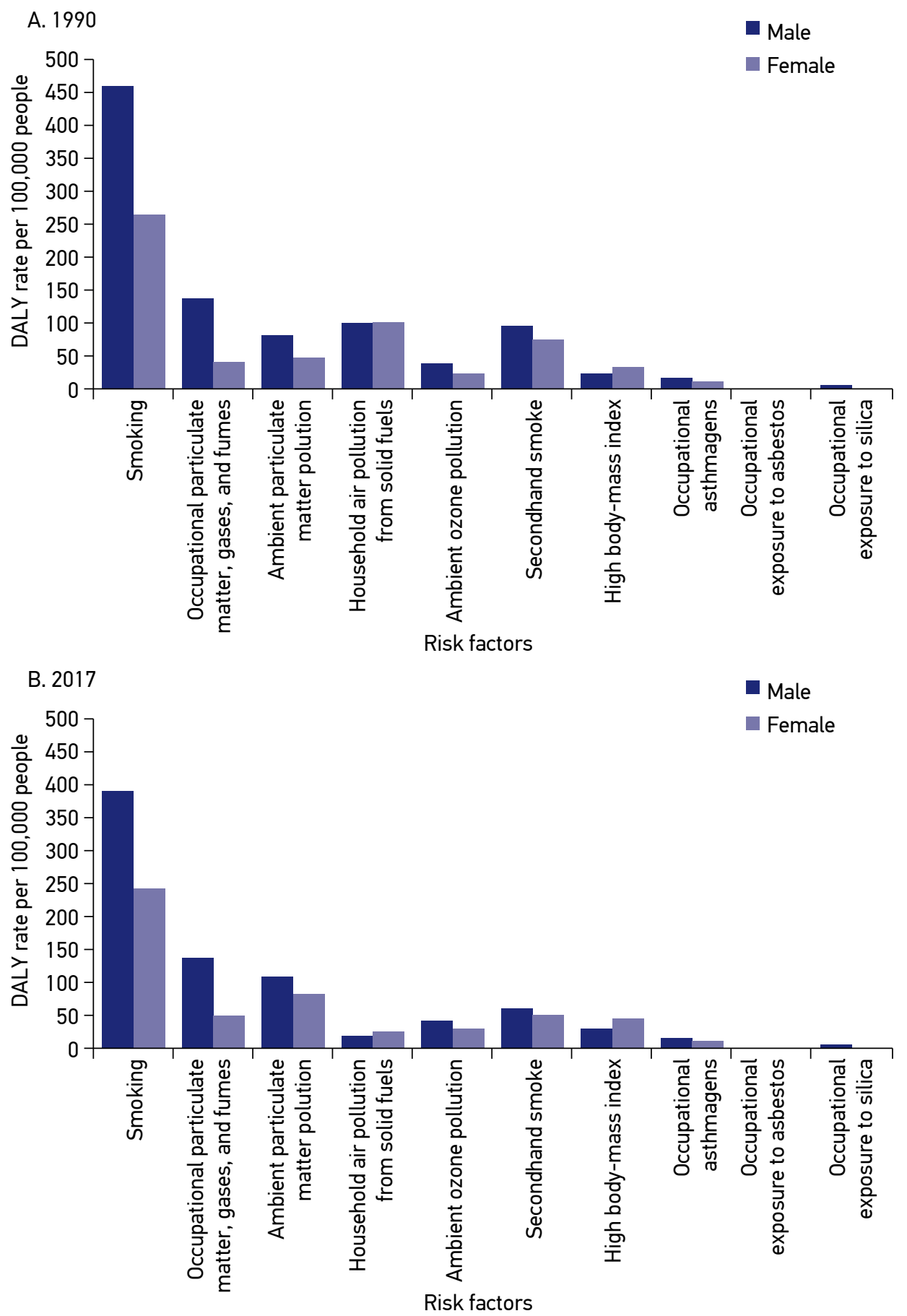

Figure 4. (A) All-ages Disability-Adjusted Life Years (DALY) rates due to chronic respiratory diseases attributable to ten risk factors, for women and men, Brazil, 1990. (B) All-ages DALY rates due to chronic respiratory diseases attributable to ten risk factors, for women and men, Brazil, 2017 
Concerning mortality estimates, a decrease in mortality rates since 1990 was shown. A similar trend was observed for cardiovascular disease $(\mathrm{CVD})^{36}$, but not for diabetes ${ }^{37}$, two important NCDs in our country. The overall mortality rates have fallen for both populations, though men remained the most affected by NCDs, including chronic respiratory conditions ${ }^{16,18}$. Remarkably, the difference in mortality between male and female estimates have been around $40 \%$, and are always higher for men. The health disparities between sexes have been broadly discussed for other conditions ${ }^{16,38-40}$ and seem to follow the same pattern as those for asthma or COPD. Several hypotheses have been proposed for the greater rates of mortality in men. They are involved in more violent situations, use alcohol and other drugs more often, and have greater exposure to traffic and work accidents ${ }^{34}$. Previous studies have described that men present later to medical care ${ }^{32,34}$, often presenting with overall poor self-care ${ }^{35}$ which might be a driver of the higher mortality rates. The Brazilian National Policy of Comprehensive Men's Health Care (in Portuguese, Política Nacional de Atenção Integral à Saúde do Homem - PNAISH) ${ }^{35}$, although carrying in-depth discussions about masculinity and health and other social issues (not addressed by our study), aimed to improve the promotion, prevention, protection, treatment and recovery of men diseases and illnesses, a starting point in tackling such disparities in healthcare attention for men.

Related to the burden of chronic respiratory diseases, the PNS 2013, to our knowledge, was the first study that assessed the burden of disease in the Brazilian population showing a severe degree of limitation for daily activities for people with either asthma or COPD (16 and $10 \%$, respectively $)^{12}$. In order to express the total burden that the loss of health imposes on the population over the years, through our study we presented the DALY rates which sum YLL to YLD estimates ${ }^{41}$. If strategies of control and management are not properly provided, the increase of DALYs due to ageing and population growth will impact all levels of the health system. In Brazil, the access to the healthcare system is low for the poorest people with important disparities depending on the region of the country ${ }^{42}$, and, although access to medication is high, it is not free of charge for these diseases ${ }^{43-45}$. Social inequalities aggravate health problems and the population over 40 years old continues to face a high degree of burden. Concerning these issues and the current lack of improvements and investments in health ${ }^{16,38,46}$, attention must be taken to avoid the burden caused by chronic respiratory conditions from becoming worse, considering the advances in estimates showed since 1990. In this sense, such indicators could be incorporated and used for decision making, whether improvements in policies to prevent and offer a better quality of life for this population are still missing.

Regarding the risk factors for chronic respiratory diseases in Brazil, we show that smoking represented the main factor in increasing the number of DALYs. Indeed, tobacco smoking is a common risk factor for many NCDs and as such the World Health Organization (WHO) and the Global Alliance against Chronic Respiratory Diseases (GARD) has initiatives to reduce tobacco consumption. Other initiatives work on issues directly related to respiratory conditions, such as medication access and reduction in occupational and allergenic exposure ${ }^{47,48}$. In Brazil, initiatives to tackle NCDs emphasize the efforts to improve policies to reduce tobacco use ${ }^{49}$. The National Tobacco Control Program $(\mathrm{PNCT})^{50}$ and all tobacco control policies are internationally recognized due to their impact on tobacco 
use prevalence, decreasing roughly $60 \%$ from 1998 to $2013^{51}$. According to results from VIGITEL $^{52}$, the reduction has occurred in every sex, age, level of education and region of Brazilian strata. Secondhand smoke which figured as a leading risk factor for DALY rates in 1990 has also decreased according to VIGITEL, an important result considering its effects as triggers for chronic respiratory diseases, especially in children ${ }^{53}$. Indeed, several measures, including the ban on advertising in the 2000s, adherence to the WHO Framework Convention on Tobacco Control in 2006, and laws that established and regulated tobacco-free environments are examples to be pursued. Also, regulation has promoted the increase of warningsand anti-smoking images on product packaging, increased taxes and defined the minimum price for their marketing, among others, representing multifaceted interventions to effectively reduce tobacco consumption. Our study represents one more source of information that highlights the importance of policies for tobacco control. There is a current discussion in Brazil evaluating reduced taxation of cigarettes manufactured in our country $^{54}$. If such policy change is enacted, it may not only lead to a worsening of health estimates, such as those presented in this study, but also reduce the likelihood of reaching, or even surpassing the target of reducing tobacco consumption by $30 \%$, according to the Global Action Plan for the Prevention and Control of NCDs ${ }^{49,52}$.

Other risk factors, such as ambient air pollution and occupational particulate matter should be mentioned. It is interesting to observe the transition among risk factors related to DALY rates from 1990 to 2017. While occupational particulate matter exhibited higher and similar rates in both years for men, in 2017 a slight increase was observed for women. In turn, ambient particulate matter pollution presented an important change, with increased rates shown in 2017. The opposite occurred for household air pollution which dropped in 2017. These results were somewhat expected, considering industrialization, migration from rural to urban areas and all environmental changes that occurred in the last few years in Brazil. According to the World Bank, Brazil is classified as an upper-middle-income economy, with industrialization increasing in recent years. Ambient and household pollution exposure are concerns for overall health conditions and targets of action by the $\mathrm{WHO}^{55}$. Pollution affects the respiratory system and has been demonstrated to not only increase the incidence of chronic respiratory diseases, but also impact those with pre-existing conditions, regardless of age ${ }^{56}$. Our results suggest an increasing burden relating air pollution and occupational exposure, the latter increasing for the female population. Thus, initiatives in this regard should be prioritized in order to understand the reasons why existing policies are not effectively reducing such burden and apply the right initiatives in reducing their impact.

This study has some limitations worth discussing. The first is related to issues with the ICD codes for COPD, ICD-10 codes J41 to J44.9. There is difficulty in differentiating ordinary chronic bronchitis from obstructive chronic bronchitis, meaning that we may overestimate COPD if we assume that all chronic bronchitis is COPD. The same misclassification of this diagnosis may happen with emphysema, as not every patient with this condition has COPD. Second, for other chronic respiratory conditions, it is not clear which acute conditions are being included, such as ICD-10 J37-J39.9, J39.0 and J39.1; these are acute pharyngeal and retropharyngeal abscesses that may increase the number of cases within this class. ICD-10 
J68 and J90 also include acute cases. Finally, GBD uses statistical methods and aggregate data. The estimates can be over- or underestimated depending on the source, in order to account for this the uncertainty interval is provided, which reflects the quality of the input data and modeling process.

In summary, our study demonstrated that the prevalence and incidence of chronic respiratory diseases, according to GBD 2017 estimates, decreased in Brazil between 1990 and 2017, with the same result for mortality rates and overall disease burden. The difference in mortality rates between men and women draws attention to the need to address these conditions for both populations. Population growth and ageing and their impact on this burden should be a concern as the disability due to COPD is related to these components. It is no surprise that smoking tobacco is the main factor related to the disability; this demonstrates that policies need to further restrict its access. We hope these results can support strategies to assist in the continuous monitoring of these conditions and the use of resources for their management.

\section{ACKNOWLEDGMENTS}

Lisiane F. L. and Ewerton C. thank the CAPES for the doctoral scholarship grant. We acknowledge Dr. Marcelo B. Gazzana for reviewing the classification of the diseases and Darrah McCracken, Pauline Kim, Adrienne Chew of the IHME, University of Washington, for their manuscript reviews and writing support. We are grateful to Dr. Bruce Duncan for presenting and supporting this project. Finally, we express thanks to the Bill \& Melinda Gates Foundation.

\section{REFERENCES}

1 BousquetJ, Weltgesundheitsorganisation, editors. Global surveillance, prevention and control of chronic respiratory diseases: a comprehensive approach. Geneva: WHO; 2007.

2 Global Initiative for Asthma (GINA). Global Strategy for Asthma Management and Prevention, 2017 [Internet]. 2017 [accessed on Nov 17, 2017]. Available at: http:/ / ginasthma.org/

3 Pavord ID, Beasley R, Agusti A, Anderson GP, Bel E, Brusselle G, et al. After asthma: redefining airways diseases. The Lancet 2017; 391(10118): 350-400. http: / / doi.org/10.1016/S0140-6736(17)30879-6

4 Beran D, Zar HJ, Perrin C, Menezes AM, Burney P. Burden of asthma and chronic obstructive pulmonary disease and access to essential medicines in lowincome and middle-income countries. Lancet Respir Med 2015; 3(2): 159-70. https://doi.org/10.1016/ S2213-2600(15)00004-1
Litonjua AA, Scott T Weiss. Epidemiology of asthma [Internet]. [accessed on Nov 10, 2017]. Available at: www.uptodate.com

6 SorianoJB, Abajobir AA, Abate KH, Abera SF, Agrawal A, Ahmed MB, et al. Global, regional, and national deaths, prevalence, disability-adjusted life years, and years lived with disability for chronic obstructive pulmonary disease and asthma, 1990-2015: a systematic analysis for the Global Burden of Disease Study 2015. Lancet Respir Med 2017; 5(9): 691-706. https:// doi.org/10.1016/ S2213-2600(17)30293-X

7 The Lancet. GBD 2017: a fragile world. The Lancet 2018; 392(10159): 1683. https://doi.org/10.1016/ S0140-6736(18)32858-7

8 Menezes AMB, Perez-Padilla R, Jardim JB, Muiño A, Lopez MV, Valdivia G, et al. Chronic obstructive pulmonary disease in five Latin American cities (the 
PLATINO study): a prevalence study. The Lancet 2005; 366(9500): 1875-81. https://doi.org/10.1016/ S0140-6736(05)67632-5

9 Montes de Oca M, Tálamo C, Perez-Padilla R, Lopez MV, Muiño A, Jardim JRB, et al. Use of respiratory medication in five Latin American cities: The PLATINO study. Pulm Pharmacol Ther 2008; 21(5): 788-93. https:/ / doi.org/10.1016/j.pupt.2008.06.003

10 Moreira GL, Manzano BM, Gazzotti MR, Nascimento OA, Perez-Padilla R, Menezes AMB, et al. PLATINO, a nine-year follow-up study of COPD in the city of São Paulo, Brazil: the problem of underdiagnosis. J Bras Pneumol 2014; 40(1): 30-7. https: / / dx.doi.org/10.159 0\%2FS1806-37132014000100005

11 Nascimento OA, Camelier A, Rosa FW, Menezes AMB, Pérez-Padilla R, Jardim JR. Chronic obstructive pulmonary disease is underdiagnosed and undertreated in São Paulo (Brazil): results of the PLATINO study. Braz J Med Biol Res 2007; 40(7): 887-95. http: / / dx.doi. org/10.1590/S0100-879X2006005000133

12 Malta DC, Stopa SR, Szwarcwald CL, Gomes NL, Silva Júnior JB, Reis AAC dos. A vigilância e o monitoramento das principais doenças crônicas não transmissíveis no Brasil - Pesquisa Nacional de Saúde, 2013. Rev Bras Epidemiol 2015; 18(Suppl. 2): 3-16. http:/ / dx.doi. org/10.1590/1980-5497201500060002

13 Travassos C, Viacava F, Laguardia J. Os Suplementos Saúde na Pesquisa Nacional por Amostra de Domicílios (PNAD) no Brasil. Rev Bras Epidemiol 2008; 11(Suppl. 1): 98-112. http: / / dx.doi.org/10.1590/S1415-790X2008000500010

14 Pinto LF, Freitas MPS de, Figueiredo AWS de. Sistemas Nacionais de Informação e levantamentos populacionais: algumas contribuições do Ministério da Saúde e do IBGE para a análise das capitais brasileiras nos últimos 30 anos. Ciênc Saúde Coletiva 2018; 23(6): 1859-70. http:/ / dx.doi.org/10.1590/1413-81232018236.05072018

15 Malta DC, França E, Abreu DMX, Perillo RD, Salmen MC, Teixeira RA, et al. Mortality due to noncommunicable diseases in Brazil, 1990 to 2015, according to estimates from the Global Burden of Disease study. Sao Paulo Med J 2017; 135(3): 213-21.

16 Marinho F, de Azeredo Passos VM, Carvalho Malta D, Barboza França E, Abreu DMX, Araújo VEM, et al. Burden of disease in Brazil, 1990-2016: a systematic subnational analysis for the Global Burden of Disease Study 2016. The Lancet 2018; 392(10149): 760-75. https://doi.org/10.1016/S0140-6736(18)31221-2

17 Institute for Health Metrics and Evaluation(IHME). GBD Compare Data Visualization[Internet]. Seattle, WA: IHME, University of Washington; 2017 [accessed on Oct 16, 2019]. Available at: http: / / vizhub.healthdata.org/gbd-compare

18 Roth GA, Abate D, Abate KH, Abay SM, Abbafati $\mathrm{C}$, Abbasi N, et al. Global, regional, and national age-sex-specific mortality for 282 causes of death in 195 countries and territories, 1980-2017: a systematic analysis for the Global Burden of Disease Study 2017. The Lancet 2018; 392(10159): 1736-88. https://doi. org/10.1016/S0140-6736(18)32203-7

19 Wang H, Naghavi M, Allen C, Barber RM, Bhutta ZA, Carter A, et al. Global, regional, and national life expectancy, all-cause mortality, and cause-specific mortality for 249 causes of death, 1980-2015: a systematic analysis for the Global Burden of Disease Study 2015. The Lancet 2016; 388(10053): 1459-544. https:// doi. org/10.1016/S0140-6736(16)31012-1

20 Hay SI, Abajobir AA, Abate KH, Abbafati C, Abbas $\mathrm{KM}$, Abd-Allah F, et al. Global, regional, and national disability-adjusted life-years (DALYs) for 333 diseases and injuries and healthy life expectancy (HALE) for 195 countries and territories, 1990-2016: a systematic analysis for the Global Burden of Disease Study 2016. The Lancet 2017; 390(10100): 1260-344. https:// doi. org/10.1016/S0140-6736(17)32130-X

21 Lima EEC de, Queiroz BL. Evolution of the deaths registry system in Brazil: associations with changes in the mortality profile, under-registration of death counts, and ill-defined causes of death. Cad Saúde Pública 2014;30(8): 1721-30. http:/ / dx.doi.org/10.1590/0102-311X00131113 22 Ishitani LH, Teixeira RA, Abreu DMX, Paixão LMMM, França EB. Qualidade da informação das estatísticas de mortalidade: códigos garbage declarados como causas de morte em Belo Horizonte, 2011-2013. Rev Bras Epidemiol 2017; 20(Suppl. 1): 34-45. http: / / dx.doi. org/10.1590/1980-5497201700050004

23 James SL, Abate D, Abate KH, Abay SM, Abbafati C, Abbasi N, et al. Global, regional, and national incidence, prevalence, and years lived with disability for 354 diseases and injuries for 195 countries and territories, 1990-2017: a systematic analysis for the Global Burden of Disease Study 2017. The Lancet 2018; 392(10159): 1789-858. https:// doi.org/10.1016/S0140-6736(18)32279-7

24 Menezes AMB, Wehrmeister FC, Horta B, Szwarcwald CL, Vieira ML, Malta DC. Prevalência de diagnóstico médico de asma em adultos brasileiros: Pesquisa Nacional de Saúde, 2013. Rev Bras Epidemiol 2015; 18(Suppl. 2): 204-13. http:/ / dx.doi. org/10.1590/1980-5497201500060018

25 Brasil. Ministério da Saúde. Vigitel Brasil 2017: vigilância de fatores de risco e proteção para doenças crônicas por inquérito telefônico : estimativas sobre frequência e distribuição sociodemográfica de fatores de risco e proteção para doenças crônicas nas capitais dos 26 estados brasileiros e no Distrito Federal em 2017. Brasil: Ministério da Saúde, Secretaria de Vigilância em Saúde, Departamento de Vigilância de Doenças e Agravos não Transmissíveis e Promoção da Saúde; 2018. 
26 Estudo de carga global de doença 2015: resumo dos métodos utilizados. Rev Bras Epidemiol 2017; 20(Suppl. 1): 4-20. http://dx.doi.org/10.1590/1980-5497201700050002 27 Salomon JA, Haagsma JA, Davis A, de Noordhout CM, Polinder S, Havelaar AH, et al. Disability weights for the Global Burden of Disease 2013 study. Lancet Glob Health 2015; 3(11): e712-e723. https:/ / doi.org/10.1016/ S2214-109X(15)00069-8

28 Gupta PD. Standardization and decomposition of rates: A user's manual. United States: US Department of Commerce, Economics and Statistics Administration, Bureau of the Census; 1993.

29 Forouzanfar MH, Afshin A, Alexander LT, Anderson HR, Bhutta ZA, Biryukov S, et al. Global, regional, and national comparative riskassessment of 79 behavioural, environmental and occupational, and metabolic risks or clusters of risks, 1990-2015: a systematic analysis for the Global Burden of Disease Study 2015. The Lancet 2016; 388(10053): 1659-724. https: / / doi.org/10.1016/S0140-6736(16)31679-8

30 Global Initiative for Chronic Obstructive Lung Disease. Global Initiative for Chronic Obstructive Lung Disease (GOLD). Global strategy for diagnosis, management and prevention of Chronic obstructive pulmonary disease (2018 report) [Internet]. 2018 [accessed on Nov 17, 2017]. Available at: http:/ / goldcopd.org/gold-reports/

31 Postma DS, Rabe KF. The Asthma-COPD Overlap Syndrome. NEngl J Med 2015; 373(13): 1241-9. https: / / doi.org/10.1056/ NEJMra1411863

32 Gomes R, Nascimento EF do, Araújo FC de. Por que os homens buscam menos os serviços de saúde do que as mulheres? As explicações de homens com baixa escolaridade e homens com ensino superior. Cad Saúde Pública 2007; 23(3): 565-74. http:/ / dx.doi.org/10.1590/ S0102-311X2007000300015

33 Moura EC de, Santos W dos, Neves ACM das, Gomes R, Schwarz E. Atenção à saúde dos homens no âmbito da Estratégia Saúde da Família. Ciênc Saúde Coletiva 2014; 19(2): 429-38. http:/ / dx.doi. org/10.1590/1413-81232014192.05802013

34 Brasil. Ministério da Saúde. Secretaria de Atenção à Saúde. Departamento de Ações Programáticas Estratégicas. Perfil da morbimortalidade masculina no Brasil [Internet]. Brasília: Ministério da Saúde; 2018 [accessed on Nov 28, 2019]. 52 p. Available at: http://bvsms.saude.gov.br/bvs/publicacoes/perfil_ morbimortalidade_masculina_brasil.pdf

35 Brasil. Portaria $\mathrm{n}^{\circ} 1.944 / 2009$. Institui no âmbito do Sistema Único de Saúde (SUS), a Política Nacional de Atenção Integral à Saúde do Homem. Diário Oficial da União [Internet] 2009 [accessed on Nov 28, 2019]. Available at: http:/ / bvsms.saude.gov.br/bvs/saudelegis/ gm/2009/prt1944_27_08_2009.html
36 Brant LCC, Nascimento BR, Passos VMA, Duncan BB, Bensenõr IJM, Malta DC, et al. Variações e diferenciais da mortalidade por doença cardiovascular no Brasil e em seus estados, em 1990 e 2015: estimativas do Estudo Carga Global de Doença. Rev Bras Epidemiol 2017; 20(Suppl. 1): 116-28. http://dx.doi. org/10.1590/1980-5497201700050010

37 Duncan BB, Schmidt MI, Cousin E, Moradi-Lakeh M, Passos VM de A, França EB, et al. The burden of diabetes and hyperglycemia in Brazil-past and present: findings from the Global Burden of Disease Study 2015. Diabetol Metab Syndr 2017; 9: 18. https: / / dx.doi. org/10.1186\%2Fs13098-017-0216-2

38 Moura EC de, Santos W dos, Neves ACM das, Schwarz E, Gomes R. Mortality in Brazil according to gender perspective, years 2000 and 2010. Rev Bras Epidemiol 2016; 19(2): 326-38. http:/ / dx.doi. org / 10.1590/1980-5497201600020010

39 Robertson S. Understanding Men and Health: Masculinity, Identity and Well-Being [Internet]. Buckingham: McGraw-Hill Education; 2007 [accessed on May 9, 2019]. Available at: http:/ / ebookcentral.proquest.com/ $\mathrm{lib} / \mathrm{mcgill} /$ detail.action?docID=332689

40 Baker P, Dworkin SL, Tong S, Banks I, Shand T, Yamey G. The men's health gap: men must be included in the global health equity agenda. Bull World Health Organ 2014; 92(8): 618-20. https:// doi.org/10.2471/ BLT.13.132795

41 Vos T, Allen C, Arora M, Barber RM, Bhutta ZA, Brown A, et al. Global, regional, and national incidence, prevalence, and years lived with disability for 310 diseases and injuries, 1990-2015: a systematic analysis for the Global Burden of Disease Study 2015. The Lancet 2016; 388(10053): 1545-602. https:// doi.org/10.1016/ S0140-6736(16)31678-6

42 Oliveira RAD de, Duarte CMR, Pavão ALB, Viacava F. Barreiras de acesso aos serviços em cinco Regiões de Saúde do Brasil: percepção de gestores e profissionais do Sistema Único de Saúde. Cad Saúde Pública 2019; 35(11): e00120718. http:/ / dx.doi. org/10.1590/0102-311x00120718

43 Leal LF, Bertoldi AD, Menezes AMB, Borges RB, Mengue SS, Gazzana MB, et al. Indicação, acesso e utilização de medicamentos para doenças respiratórias crônicas no Brasil: resultados da Pesquisa Nacional sobre Acesso, Utilização e Promoção do Uso Racional de Medicamentos no Brasil(PNAUM), 2014. Cad Saúde Pública 2018; 34(10). http: / / dx.doi.org/10.1590/0102-311x00208217

44 Luiza VL, Tavares NUL, Oliveira MA, Arrais PSD, Ramos LR, Pizzol T da SD, et al. Catastrophic expenditure on medicines in Brazil. Rev Saúde Pública 2016; 50(Suppl. 2). http:/ / dx.doi.org/10.1590/s1518-8787.2016050006172 
45 Tavares NUL, Luiza VL, Oliveira MA, Costa KS, Mengue SS, Arrais PSD, et al. Free access to medicines for the treatment of chronic diseases in Brazil. Rev Saúde Pública 2016; 50(Suppl. 2). http:/ / dx.doi.org/10.1590/ s1518-8787.2016050006118

46 Doniec K, Dall'Alba R, King L. Brazil's health catastrophe in the making. The Lancet 2018; 392(10149): 731-2. https: / / doi.org/10.1016/S0140-6736(18)30853-5

47 World Health Organization. Global alliance against chronic respiratory diseases (GARD) basket: a package of information, surveillance tools and guidelines, to be offered as a service to countries. United States: Department of Chronic Diseases and Health Promotion; 2008.

48 Cruz AA, Camargos PA, Urrutia-Pereira M, Stelmach R. Global Alliance against Chronic Respiratory Diseases (GARD) Brazil success case: overcoming barriers. J Thorac Dis 2018; 10(1): 534-8. https: / / dx.doi. org/10.21037\%2Fjtd.2018.01.40

49 Brasil. Ministério da Saúde. Plano de ações estratégicas para o enfrentamento das doenças crônicas não transmissíveis (DCNT) no Brasil: 2011-2022. Brasília: Ministério da Saúde; 2011.

50 Instituto Nacional de Câncer José Alencar Gomes da Silva. Comissão, Nacional para Implementação da ConvençãoQuadro para controle do Tabaco (CONICQ). Política Nacional de controle do tabaco: relatório de gestão e progresso 2011-2012 [Internet]. Rio de Janeiro: INCA; 2014 [accessed on Oct 20, 2017]. 132 p. Available at: http://bvsms.saude.gov.br/bvs/publicacoes/politica_ nacional_controle_tabaco_relatorio_gestao.pdf

51 Malta DC, Silva AG da, Machado ÍE, Sá ACMGND, Santos FM dos M, Prates EJS, et al. Trends in smoking prevalence in all Brazilian capitals between 2006 and 2017. J Bras Pneumol 2019; 45(5): e20180384. https: / / doi.org/10.1590/1806-3713/e20180384

52 Malta DC, Stopa SR, Santos MAS, Andrade SSC de A, Oliveira TP, Cristo EB, et al. Evolução de indicadores do tabagismo segundo inquéritos de telefone, 20062014. Cad Saúde Pública 2017; 33(Suppl. 3). http:/ / doi.org/10.1590/0102-311x00134915

53 Lenney W, Bush A, Fitzgerald DA, Fletcher M, Ostrem A, Pedersen S, et al. Improving the global diagnosis and management of asthma in children. Thorax 2018; 73: 662-9. http:/ / dx.doi.org/10.1136/ thoraxjnl-2018-211626 54 Brasil. Ministério da Justiça e Segurança Pública/ Gabinete do Ministro. Portaria ${ }^{\circ}$ 263, de 23 de março de 2019. Institui Grupo de Trabalho, no âmbito do Ministério da Justiça e Segurança Pública, para avaliar a conveniência e oportunidade da redução da tributação de cigarros fabricados no Brasil [Internet]. [accessed on May 10, 2019]. Available at: http:/ / www.in.gov.br/ materia/-/asset_publisher/Kujrw0TZC2Mb/content/ id/ 68561661/ do1-2019-03-26-portaria-n-263-de-23-demarco-de-2019-68561465

55 World Health Organization. How airpollution is destroying our health [Internet]. [accessed on Dec 10, 2019]. Available at: https:/ /www.who.int/airpollution/news-and-events/ how-air-pollution-is-destroying-our-health

56 Arbex MA, Santos U de P, Martins LC, Saldiva PHN, Pereira LAA, Braga ALF. A poluição do ar e o sistema respiratório. J Bras Pneumol 2012; 38(5): 643-55. http:/ / dx.doi.org/10.1590/S1806-37132012000500015

Received on: 09/25/2019

Revised on: 12/11/2019

Approved on: 12/16/2019

Authors' contribution: Lisiane F. Leal and Ewerton C.: article design, analysis, writing, and critical review of the manuscript. Augusto B. Bidinotto, Daniel Sganzerla, Rogério B. Borges: analysis and critical review of the manuscript. Deborah C. Malta, Kevin Ikuta, Tatiane da S. D. Pizzol: writing, and critical review of the manuscript. 